\title{
Comparison of the Toxicities of Ethylene Vinyl Alcohol Copolymer Preparations, Dimethyl Sulphoxide and N-Butyl 2-Cyanoacrylate on Cerebral Parenchyma in an Experimental Rabbit Model
}

\author{
Deneysel Tauşan Modelinde Etilen Vinil Alkol Kopolimer Preparatlar, \\ Dimetil Sülfoksid ve N-Bütil 2-Siyanoakrilat'in Serebral Parankim \\ Üzerindeki Toksik Etkilerinin Karşılaștırnlması
}

Cagatay OZDOL ${ }^{1}$, Cezmi Cagri TURK ${ }^{1}$, Derya Burcu HAZER ${ }^{2}$, Ali Erdem YILDIRIM ${ }^{3}$, Anil ARAT ${ }^{4}$, Pergin ATILLA ${ }^{5}$, Sevda MUFTUOGLU ${ }^{5}$, Hakan ORUCKAPTAN ${ }^{6}$

${ }_{1}^{1}$ Antalya Education and Research Hospital, Department of Neurosurgery, Antalya, Turkey

${ }^{2}$ Muğla University, School of Medicine, Department of Neurosurgery, Mugla, Turkey

${ }^{3}$ Ankara Numune Education and Research Hospital, Department of Neurosurgery, Ankara, Turkey

${ }^{4}$ Hacettepe University, School of Medicine, Department of Radiology, Ankara, Turkey

${ }^{5}$ Hacettepe University, School of Medicine, Department of Histology and Embryology, Ankara, Turkey

${ }^{6}$ Liv Hospital, Department of Neurosurgery, Istanbul, Turkey

Corresponding Author: Cagatay OZDOL / E-mail: drcagatayozdol@gmail.com

ABSTRACT

AIM: Ethylene vinyl alcohol copolymer (EVOH), its organic solvent dimethyl sulfoxide (DMSO), and N-Butyl 2-Cyanoacrylate (NBCA) are widely used in neurovascular embolization procedures and yet with potential risk of cytotoxicity. The aim of this study was to evaluate the toxic effect of EVOH-DMSO, its solvent DMSO and NBCA on cerebral parenchyma in a rabbit model.

MATERIAL and METHODS: Forty-eight albino male rabbits were divided into 6 groups based on the substance injected into the parenchyma; normal saline, DMSO, NBCA, 6\% EVOH-DMSO and 20\% EVOH-DMSO and control group. At 72 hours the subjects were sacrificed and brain samples were harvested for histopathological examination and lipid peroxidase measurements.

RESULTS: Neuronal degeneration and inflammatory reaction in the brain parenchyma was prominent especially in DMSO group and EVOHDMSO groups. Furthermore, the extent of degeneration and inflammatory reaction was related to the concentration of the embolic agent in the EVOH group. Lipid peroxidase activity was significantly increased in the NBCA group as compared to all but to $20 \%$ EVOH-DMSO group.

CONCLUSION: EVOH and its solvent DMSO cause degeneration and inflammatory reaction in brain parenchyma and for EVOH this reaction was appeared to be dose dependent.

KEYWORDS: Cerebral parenchyma, Cerebrovascular diseases, N-Butyl 2-Cyanoacrylate, Embolization, Ethylene vinyl alcohol copolymer, DMSO, Toxicity

öz

AMAÇ: Etilen Vinil Alkol Kopolimer (EVOH), organik solventi dimetil sülfoksid (DMSO) ve N-Bütil 2-Siyonoakrilat (NBCA) potansiyel olarak sitotoksik özellikler taşıyan ve sıklıkla nörovasküler embolizasyon işlemlerinde kullanılan maddelerdir. Bu çalışma ile EVOH-DMSO ile solventleri olan DMSO ve NBCA'nın serebral parankim üzerindeki toksik etkileri deneysel tavşan modelinde araştırılmıştır.

YÖNTEM ve GEREÇLER: Çalışmada kırksekiz erkek albino tavşan kullanıldı ve beyin parankimine enjekte edilen maddelere göre tavşanlar 6 gruba ayrıldı. Kontrol grubu dışındaki tavşanlara normal salin, DMSO, NBCA, \%6'lık EVOH-DMSO ve \%20 lik EVOH-DMSO verildi. Tavşanlar yakın nörolojik takip altında tutuldu. 72 saat sonra tavşanlar sakrifiye edildi ve beyin dokusu çıkarılarak histopatolojik inceleme ve lipid peroksidaz ölçümleri için hazırlandı.

BULGULAR: Özellikle DMSO ve EVOH-DMSO gruplarında nöronal dejenerasyon ve inflamatuvar reaksiyonlar belirgindi. Dahası, EVOH grubunda dejenerasyon ve inflamasyon düzeyi, kullanılan embolizan ajan konsantrasyonu ile ilişkiliydi. Lipid peroksidaz aktivitesinin \% $20^{\prime}$ lik EVOH-DMSO grubu dışındaki diğer gruplara nazaran belirgin olarak NBCA grubunda arttığı tespit edildi.

SONUÇ: EVOH ve solventi DMSO beyin parankiminde dejenerasyona ve inflamatuvar reaksiyona yol açmaktadır ve bu etki EVOH için doz ilişkilidir.

ANAHTAR SÖZCÜKLER: Serebral parankim, Serebrovasküler hastalık, N-Butil 2-Siyanoakrilat, Embolizasyon, Etilen vinil alkol kopolimer, DMSO, Toksisite 


\section{INTRODUCTION}

The endovascular management of arteriovenous malformations (AVM) dates back to 1960s, when Luessenhop first described angiographic treatment of AVMs by using plastic or steel materials as embolizing agents (13). Today, the selection of embolizing agent is quite challenging as the number of alternatives increased through years (2). Ethylene Vinyl Alcohol Copolymer (EVOH) and N-Butyl 2-Cyanoacrylate (NBCA) were mainly used for embolization procedures (slow vs. rapid embolizing agents, respectively) former one being more preferred after year $2000(8,20)$.

The management of AVMs and aneurysms by endovascular techniques is not free of complications. The rates of technical and embolization-related complications have been reported as $6 \%$ and $12 \%$, respectively. The technical complications include micro-catheter entrapment and peripheral vessel perforations, whilst, embolization-induced hemorrhage was reported in $4-16 \%$ of the cases, leading to disabilities or even death $(10,22)$.

There are some previous studies regarding leakage of EVOHDMSO into subarachnoid space (2). Acute subarachnoid hemorrhage, low-grade microglial encephalitis, inflammatory cell infiltrations, necrosis and perivascular lymphocytes accumulations were among reported complications (3). There are also some reports for the angiotoxic and neurotoxic effects of the solvent DMSO and NBCA. Bakar et al. have studied the effects of embolizing agents, leaking into subarachnoid space and calling attention to the paucity of data in the medical literature about toxic effects of embolizing agents and its components on brain tissue (2).

This study aimed at demonstrating histological and biochemical effects of widely used embolizing agents and its components; NBCA, EVOH and DMSO upon contacting with neural parenchyma.

\section{MATERIAL and METHODS}

This experiment was performed in accordance with the guidelines for the use of laboratory animal subjects in research set by the Ethical Committee of Hacettepe University (04.02.2005\2005\1-1).

Forty-eight domestic male albino rabbits, weighting 4-5 kg were used for the experiment. The animals were randomly allocated into 6 groups ( 8 animals in each group):

Group 1: DMSO group (DMSO, Microtherapeoutic Inc. Irvine, (A, USA)

Group 2: 6\% EVOH-DMSO Group (Onyx 18, Onyx ${ }^{\circledast}$ Liquid Embolic System, Microtherapeoutic Inc., Irvine, CA, USA)

Group 3: 20\% EVOH-DMSO Group (Onyx 500, Onyx ${ }^{\oplus}$ Liquid Embolic System, Microtherapeoutic Inc., Irvine, CA, USA)

Group 4: 30\% NBCA Lipiodol mixture (Histoacryl ${ }^{\circledR}$, B. Braun Melsungen AG, Germany; Lipiodol Ultra-Fluid, Guerbet, France)
Group 5: Saline Group (normal saline solution)

Group 6: Control Group (no chemical infusion)

All animals were anesthetized with intramuscular injection of ketamine $10 \%(40 \mathrm{mg} / \mathrm{kg})$ and xylazine $2 \%(5 \mathrm{mg} / \mathrm{kg})$, and kept on spontaneous respiration at room temperature. The animals were placed into prone position and skin incision on the mid-pupillary line was made in frontal area in front of coronal suture. A burr hole was drilled in the frontal bone and after opening the dura, $0.05 \mathrm{cc}$ of each particular substance of the groups was injected slowly by using a delivery syringes into the brain parenchyma $(0.5 \mathrm{~cm})$, under direct visualization and withdrawal technique to ensure inadvertent ventricular puncture. The injection site was $1 \mathrm{~cm}$ in front of the coronal suture and $1 \mathrm{~cm}$ lateral to the sagittal suture. The control group was also operated, even opening the dura, but without any injections. The rabbits were followed for spontaneous recovery from anesthesia under the blanket.

The rabbits were then moved to their cages where kept at room temperatures and fed ad libitum for 72 hours. Later on, the rabbits were sacrificed with high-dose anesthesia. Then, all animals were exposed to cerebral perfusion by physiological saline solution via the transcardiac route after thoracotomy and they were then decapitated. The cerebral tissues were harvested particularly including $1 \mathrm{~cm}$ periphery of the injection sites for histopathological and biochemical examinations (Figure 1A). The specimens were stored in 10\% buffered formaldehyde solution at room temperature and at $-30^{\circ} \mathrm{C}$ at dry air for particular examinations, respectively.

\section{For Materials Used in this Experiment}

EVOH-DMSO solutions contained EVOH as an embolizing agent, DMSO as a solvent for liquid delivery of EVOH and micronized tantalum powder as radiographic viewer. Pure liquid DMSO was approximately $1.10 \mathrm{mg} \backslash \mathrm{ml}$ in concentration.

\section{Neurological Evaluation}

The rabbits were evaluated for several parameters; infections, ataxia, difficulty in feeding, paresis, opisthotonus, up-ward gaze palsy, aggressive behavior and apathy twice a day.

\section{Specimen Analysis}

All specimens were evaluated by an experienced biochemist blinded to the animal groups, solvent, and the embolizing materials. Biochemical analyses were performed by thiobarbituric acid application, and then a $532 \mathrm{~nm}$ spectrophotometer (Shimadzu ${ }^{\oplus}$ UV-120-02 spectrophotometer) was used for measuring the lipid peroxidation levels in volumes of nanomoles per gram of wet tissue (14).

For histological examination, all tissue samples were fixed at $10 \%$ buffered formaldehyde and handled according to a routine light microscopic tissue processing technique. Serial sections of $6 \mu \mathrm{m}$, stained with hematoxylene-eosin, were examined and photographed by an Olympus $\mathrm{BH}-2$ microscope. 
Each of the three sections was evaluated independently by two histologists blinded to the groups. Any disagreements were resolved by a third experienced histolopathologist. Five random regions were examined at 40X magnification; glial cells, normal-appearing neurons and pyknotic neurons and the inflammatory cells were counted in each section. The results of the two histologists were compared and an average number of cells per $1 \mathrm{~mm}^{2}$ was determined.

\section{Statistical Analysis}

The study results consisted of cell counts for glial cells, neurons and pyknotic neurons and inflammatory cell counts. Data was expressed as mean \pm standard deviation for continuous variables and number or percentage of subjects for categorical ones. Continuous variables were compared by Student t-test or the Mann-Whitney rank sum test. Statistical analyses were performed using SPSS software package (SPSS Inc., Chicago, Illinois, USA) version 11.0 for Windows and $p<$ 0.05 was considered statistically significant.

\section{RESULTS}

\section{Neurological Examination}

In the experiment, none of the rabbits had infection and up-ward gaze palsy in the postoperative period. The most common neurological findings were ataxia and paresis, observed in 6 and 9 animals, respectively. The paresis was more common in rabbits in the $20 \%$ EVOH-DMSO group. Apathy was observed in 3 rabbits, one rabbit each in the EVOH-DMSO groups and one in the DMSO group (Table I). The neurological findings were not statistically significant.

\section{Histopathological Examinations}

\section{Light microscopy}

In the control (Figure 1B) and saline groups (Figure 1C, D), neuropil in-between the neurons with euchromatic nuclei demonstrated a normal architecture, with minute numbers of pyknotic cells having an apoptotic appearance in the saline group. There was neither engorgement and stasis in the vessel nor bleeding.

The edema in the neuropil was determined by scattered or widely dispersed separation between the architecture. The edema was mild in the DMSO group (Figure 1E, F) with scattered separations, while separation in the architecture was incrementing from $6 \%$ to $20 \%$ EVOH-DMSO groups, with severe separation in the neuropil (Figure 1G-K). The edema was also severe in NBCA group (Figure 1L-M).

The predominant cells were neurons with euchromaticnuclei in DMSO group with scarce numbers of pyknotic cells, which is also true for both $6 \%$ EVOH-DMSO and NBCA groups with higher numbers of pyknotic cells. However, this figure is varied in case of $20 \%$ EVOH-DMSO group, in which normal appearing neurons significantly lost and pyknotic and apoptotic cells dominated the sections.

The bleeding areas and erythrocytes collections in the vessels were mostly seen in the EVOH-DMSO groups, with increasing predominance with concentration.

\section{Cell count results}

Statistical analysis of the number of normal neurons, pyknotic neurons and glial cells revealed no difference between saline and control groups. However EVOH-DMSO group had a lower number of normal appearing neuronal cells compared to the control, saline, and NBCA and DMSO groups. This difference in the cell count was apparently proportional to the concentration of EVOH-DMSO and the higher the concentration, the more pronounced the decrease in cell count (Figure 2). A reverse to the allegory was true for normally appearing cells; as the concentration of the EVOH increased, the pyknotic cell number increased (Figure 3 ). The intergroup differences regarding the number of normally appearing cells, pyknotic cells and glial cells were evaluated with Kruskal-Wallis multiple comparison test and the difference was statistically significant $(p<0.001)$ (Figure 3,4$)$.

\section{Lipid Peroxidase activity}

All the values for lipid peroxidases were recorded and evaluated for homogeneity of the groups. As the groups were not homogenous, significance of differences between the groups was sequentially analyzed with Kruskal-Wallis Multiple Comparison Test and no significant difference was detected between experimental groups ( $p>0.05)$. There was no significant difference among the groups except for significantly increased activity in the NBCA group (0.33 \pm 0.04$)$ as compared to all groups except for $20 \%$ EVOH-DMSO group $(0.29 \pm 0.06)$ (Figure 5).

\section{DISCUSSION}

EVOH-DMSO is an easily injectable embolic material through a micro-catheter. It is composed of three materials; the main component being EVOH for precipitation and formation of a spongy polymer cast, DMSO as the solvent and micronized tantalum powder for radiographic viewing $(19,23)$. Being a non-adhesive liquid per se, upon contacting with blood, the solvent (DMSO) dissolves and EVOH precipitates, forming a polymer cast for blocking the blood flow distally, either into aneurysm or AVMs (15). However, medical application of these materials in management of AVMs may be deceiving in terms

Table I: Neurological Examination Findings Among Groups; n(\%)

\begin{tabular}{|l|c|c|c|c|} 
& $6 \%$ EVOH-DMSO & $20 \%$ EVOH-DMSO & DMSO & NBCA \\
\hline Ataxia & $2(25)$ & $2(25)$ & $1(12.5)$ & $1(12.5)$ \\
\hline Paresis & $2(25)$ & $4(50)$ & $2(25)$ & $1(12.5)$ \\
\hline Apathy & $1(12.5)$ & $1(12.5)$ & $1(12.5)$ & $0(0)$
\end{tabular}




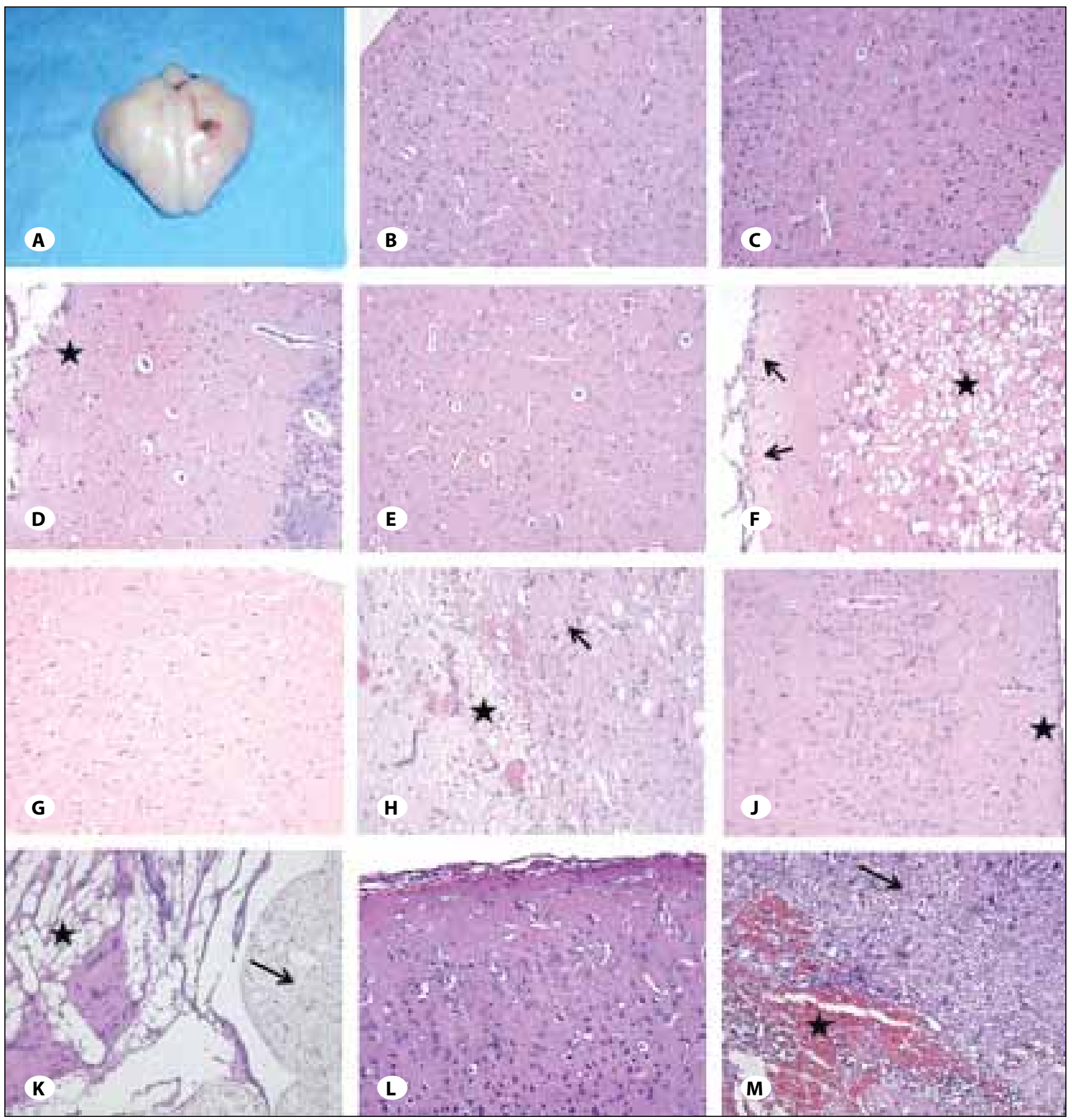

Figure 1: A) The macroscopic evidence of the whole cerebrum following administration of 20\% EVOH-DMSO. B) Control group: capillaries and glial cells between neurons with euchromatic nuclei. [Hematoxylin-Eosin (HE) x20]. C, D) Saline group: Pkynotic neurons in some parts between the euchromatic neurons (C) and edema under the piamater and neuropil (star) (D). E, F) DMSO group: a few pkynotic neurons are present between the euchromatic neurons. There is perivascular edema in some vessels but no dilatation and stasis (E). Mild edema (arrows) under the piamater but severe edema in the deep cortex (star) (F). G, H) 6\% EVOH-DMSO group: edema under the piamater and neuropil together with many pyknotic neurons and increase in the number of glial cells (G). Severe edema in the neuropil in the cortex and medulla, with a hemorrhagic area (star) and increase in the number of glial cells $(\mathrm{H})$. J, K) 20\% EVOH-DMSO group: many pkynotic neurons in the cortex and edema (star) under the piamater and neuropil (J), severe edema (star), degenerated neurons and infiltrative cells are present at the side of onyx (arrow) (K). L, M) NBCA group: edema under the piamater and perivascular edema is obvious (L). In the deep cortex, edema in the neuropil (arrow) and hemorrhage (star) is seen. There are degenerated neurons and infiltrative cells near the hemorrhagic area (M). [Hematoxylin-Eosin (HE) x20]. 


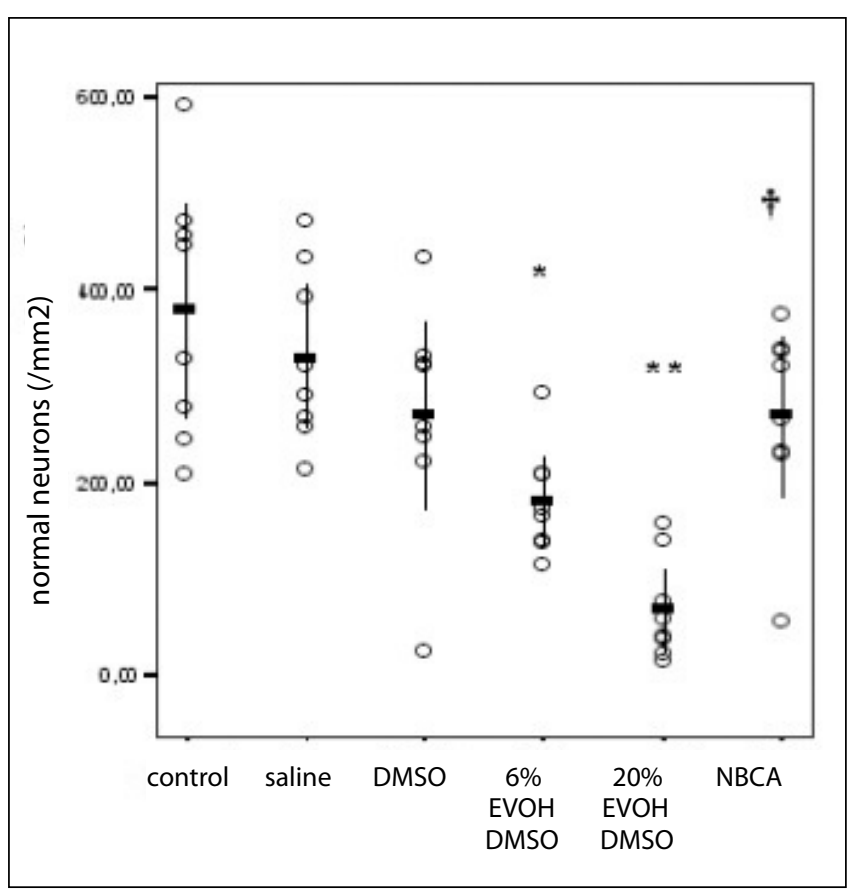

Figure 2: Normal neuronal cell count among groups.

* vs. control, $p=0.002 ;$ vs. saline, $p=0.001$; vs. NBCA, $p=0.048$

** vs. control, and saline, $p<.0001$; vs. DMSO, 6\% EVOH-DMSO, and NBCA, $\mathrm{p}<.0001$

$\dagger$ vs. control, $p=0.090$.

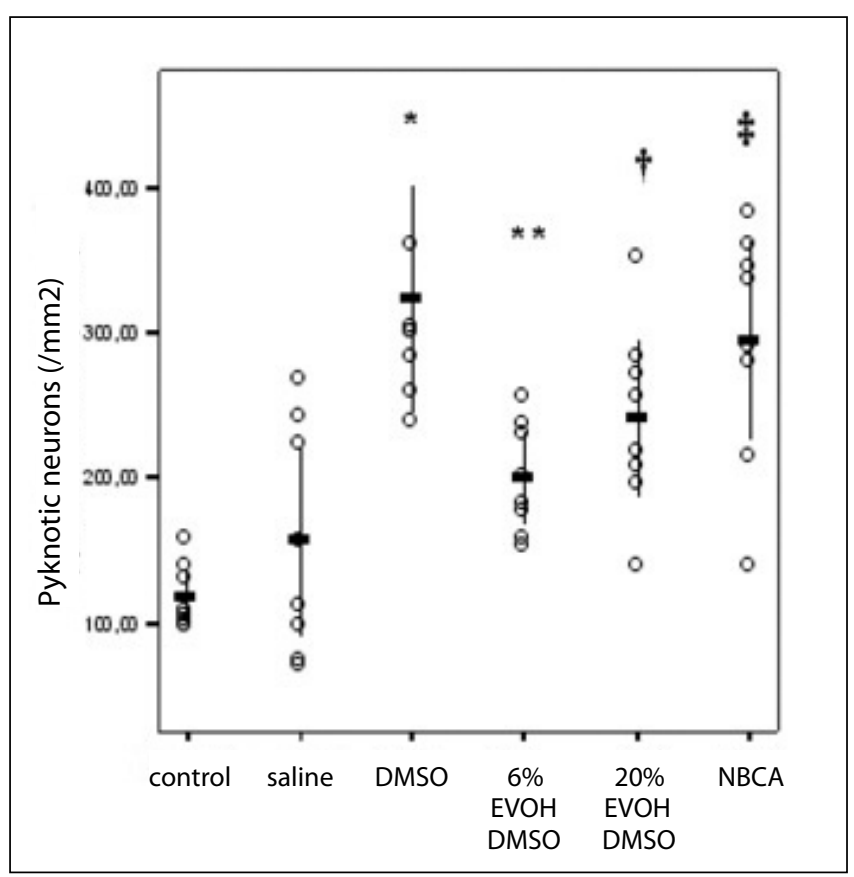

Figure 3: Pyknotic cell count among groups.

* vs. control, $p<.0001$; vs. saline and $6 \%$ EVOH-DMSO, $p=0.001$; vs. $20 \%$ EVOH-DMSO, $\mathrm{p}=0.044$

** vs. control, $\mathrm{p}<.0001$

† vs. control, $\mathrm{p}<.0001 ; \mathrm{vs}$. saline, $\mathrm{p}=0.034$;

₹ vs. control, $p<.0001$; vs. saline, $p=0.004$; vs. $6 \%$ EVOH-DMSO, $\mathrm{p}=0.010$ of biocompatibility, as angiotoxic and neurotoxic effects have been reported particularly for DMSO previously $(1,5)$.

NBCA, representing a group of rapidly polymerizing adhesives, has been used in embolization of some vascular diseases (18, 21). As soon as these agents are injected into the arteries, anions in the blood initiated a series of reactions, leading to a formation of polymer chain. However, toxic effects of these agents, ipso facto NBCA, have been shown on neural tissues and vessel walls, when infused into intravascular lumen (6). The formation and release of acrylacetate and formaldehyde, through the polymerization reactions, was held responsible from these toxic and inflammatory reactions (11).

The aforementioned toxicities were not studied in detail so that which particular component of these mixtures was responsible for these effects is left obscure. Intracarotid administration of DMSO was reported to cause irreversible changes in endothelial and smooth muscle cells, emphasizing the importance of avoiding any inadvertent insults on vessel walls (17). However, in contrast to these reports, DMSO was also shown to distribute diffusely to whole body, even if applied to the skin or mucosa, and possibly with some antioxidant, antiinflammatory and anti-ischemic properties $(7,9)$. Bakar et al. studied the effects of DMSO infusion through the intracarotid route and concluded that the solvent is not toxic to vessels and neuronal tissue and there was no alteration in the blood brain barrier (1).

The neuronal toxicity following intracarotid injection of EVOH was addressed previously in the literature. Sampei et

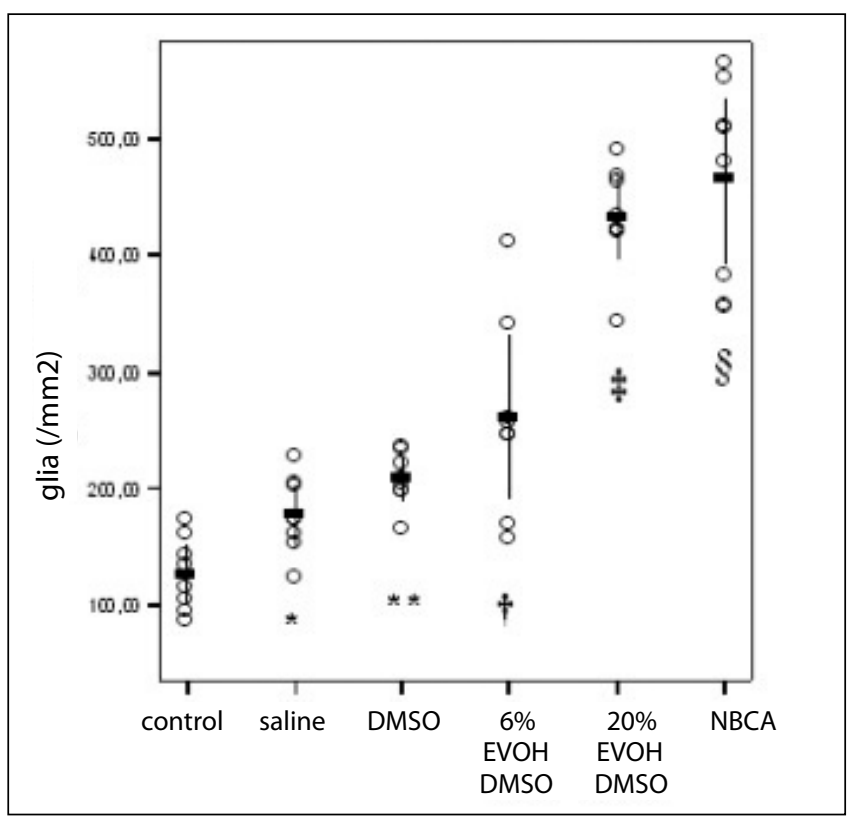

Figure 4: Glial cell count among groups.

* vs. control, $\mathrm{p}=0.007$

** vs. control, $p<.0001 ;$ vs. saline, $p=0.043$

† vs. control, $p=0.001$; vs. saline, $p=0.020$

\# vs. control, saline, DMSO and 6\% EVOH-DMSO, $p<.0001$

$\S$ vs. control, saline, DMSO and 6\% EVOH-DMSO, $\mathrm{p}<.0001$. 


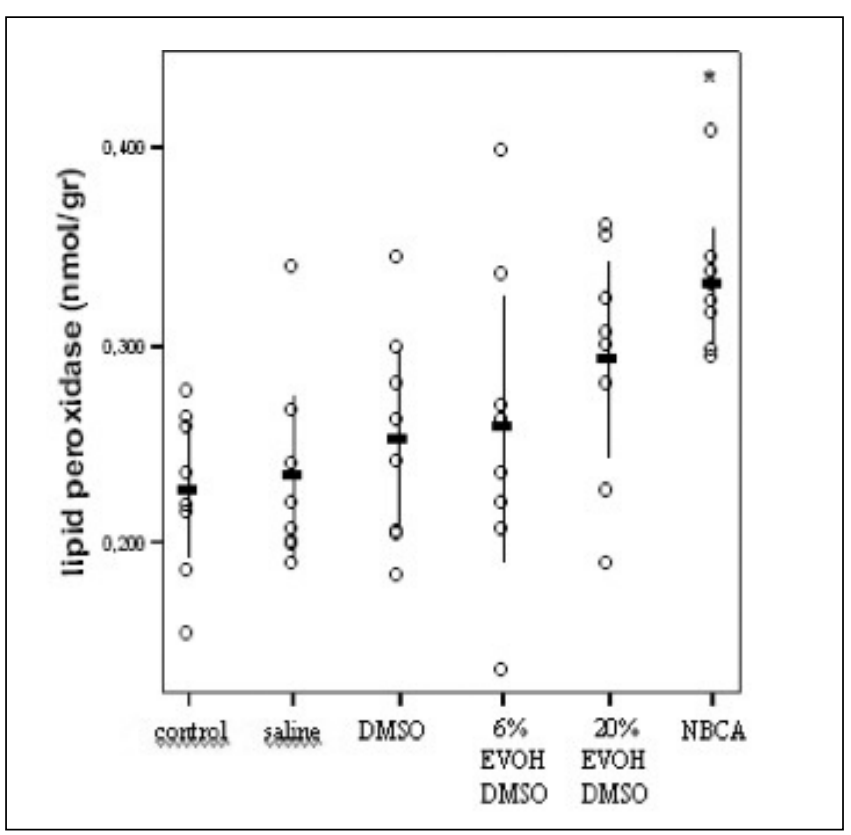

Figure 5: Lipid peroxidase activity among groups.

* vs. control, saline and DMSO, $\mathrm{p}<0.01$; vs. $6 \%$ EVOH-DMSO, $p=0.046$; vs. $20 \%$ EVOH-DMSO, $p=0.26$.

al. showed that there were a concentration-related toxicity in the brain parenchyma following intraarterial injection of high-concentrations (70\%) of $\mathrm{EVOH}$, causing destruction in the vessel wall and inherently the blood brain barrier, resulting in brain edema (17). However, neuronal toxicity was not reported at concentrations used for AVM (6\% and 6,5\%) or aneurysm embolizations (20\%).

In the present study, the results showed that when EVOH and DMSO were administered into brain parenchyma separately, they cause edema, neuronal degeneration and mild apoptosis more than observed in the control groups. The effects on the numbers of pyknotic cells, normally-appearing neurons and glial cell counts were most significantly affected in those receiving the $20 \%$ EVOH-DMSO mixture, followed by the $6 \%$ mixture and DMSO groups. There was concentrationrelated toxicity with these materials. The most striking finding was neuronal degeneration, mainly caused by the main component, EVOH, itself, rather than its solvent, DMSO.

Regarding NBCA groups, tissue reactions were mostly observed in and around the vascular structures (4). This may suggest the toxic effects of NBCA resulting from both foreign body reactions and from damaged vascular walls (16). Moreover, these reactions were reported to cause further obliteration in the vessel, per se (12). Our figures demonstrated similar effects of NBCA with DMSO in terms of numbers of normal-appearing and pyknotic neurons. However this finding was not also true for the glial cells. In fact, the numbers even exceeded those observed in the $20 \%$ EVOH-DMSO groups. This finding was also supported by the results of Bakar et al.; indicating NBCA has more toxic activities than DMSO and EVOH-DMSO (6\% and 20\%).
The lipid peroxidase levels demonstrated no major differences among the groups, excluding NBCA. The results may indicate a positive contribution of DMSO to decreasing free radical formation in the tissues, as the figures did not reach statistically significant values in the groups receiving DMSO, but did so in the NBCA group (18). These figures are similar to those in the literature (2).

EVOH-DMSO was commercially available in different designations; 18, 20, 34 centipoise and HD 500 with particular concentrations of $\mathrm{EVOH} ; 6 \%, 6.5 \%, 8 \%$ and $20 \%$, respectively. In practice, concentrations of $6 \%$ and $6.5 \%$ were mainly used in embolization procedures for AVM's, whereas 20\% (HD500) was preferred in the management of aneurysms (19). From an anatomical perspective, our study may be more specific for AVMs because of the higher risk of observing intracerebral rather than subarachnoid hemorrhage in case of a bleeding. Our results indicated more favorable risks of using lower concentrations of EVOH-DMSO in the management of AVMs in order to alleviate, at least from toxic effect of the agents, irreversible damages by dooming intracerebral bleeding.

\section{CONCLUSION}

This study was the first to evaluate the possible toxic effects of embolizing agents and their components on neural tissues. In contrast to current knowledge, the toxic effects of the EVOH- DMSO mixture were majorly incurred and governed by $\mathrm{EVOH}$ itself, rather than DMSO. As the risk of intracerebral bleeding is higher in the management of AVMs (compared to aneurysms), safer use of low concentrations of the EVOHDMSO mixture is advocated.

\section{REFERENCES}

1. Bakar B, Kose EA, Sonal S, Alhan A, Kilinc K, Keskil IS: Evaluation of the neurotoxicity of DMSO infused into the carotid artery of rat. Injury 43:315-322, 2012

2. Bakar B, Oruckaptan HH, Hazer BD, Saatci I, Atilla P, Kilic K, Muftuoglu SF: Evaluation of the toxicity of onyx compared with n-butyl 2-cyanoacrylate in the subarachnoid space of a rabbit model: An experimental research. Neuroradiology 52: 125-134, 2010

3. Brayton CF: Dimethyl sulfoxide (DMSO): A review. Cornell Vet 76:61-90, 1986

4. Brothers MF, Kaufmann JC, Fox AJ, Deveikis JP: N-Butyl2-cyanoacrylate. Substitute for IBCS in interventional neuroradiology: Histopathologic and polymerization time studies. AJNR Am J Neuroradiol 10:777-786, 1989

5. Chaloupka JC, Huddle DC, Aldeman J, Fink S, Hammond $\mathrm{R}$, Vinter HV: A reexamination of the angiotoxicity of superselective injection of DMSO in the swine rete embolization model. AJNR Am J Neuroradiol 20: 401-410, 1999

6. Duffner F, Ritz R, Bornemann A, Freudenstein D, Wiendl H, Siekmann R: Combined therapy of cerebral arteriovenous malformations: Histological differences between a nonadhesive liquid embolic agent and n-butyl 2-cyanoacrylate (NBCA). Clin Neuropathol 21:13-17, 2002 
7. Freeman BA, Crapo JD: Biology of disease: Free radicals and tissue injury. Lab Invest 47:412-426, 1982

8. Hamada J, Kai Y, Morioka M, Kazekawa K, Ishimaru Y, Iwata $\mathrm{H}$, Ushio $\mathrm{Y}$ : A mixture of ethylene vinyl alcohol copolymer and ethanol yielding a nonadhesive liquid embolic agent to treat cerebral arteriovenous malformations: Initial clinical experience. J Neurosurg 97: 881-888, 2002

9. Kaye TS, Egorin MJ, Riggs CE Jr, Olman EA, Chou FT, Salcman $M$ : The plasma pharmacokinetics and tissue distrution of dimethyl sulfoxide in mice. Life Sci 33:1223-1230, 1983

10. Ledezma CJ, Hoh BL, Carter BS, Pryor JC, Putman CM, Ogilvy CS: Complications of cerebral arteriovenous malformation embolization: Multivariate analysis of predictive factors. Neurosurgery 58:602-611, 2006

11. Levrier O, Mekkaoui C, Rolland PH, Murphy K, Cabrol P, Moulin G, Bartoli JM, Rayboud C: Efficacy and low vascular toxicity of embolization with radical versus anionic polymerization of n-butyl-2-cyanoacrylate (NBCA). An experimental study in the swine. J Neuroradiol 30:95-102, 2003

12. Lieber BB, Wakhloo AK, Siekmann R, Gounis MJ: Acute and Chronic swine rete arteriovenous malformation models: Effect of ethiodol and glacial acetic asid on penetration, dispersion and injection force of $\mathrm{n}$-buyl-2-cyanoacrylate. Am L Neuroradiol 26:1707-1714, 2005

13. Luessenhop AJ, Spence WT: Artificial embolization of cerebral arteries: Report of use in a case of arteriovenous malformation. JAMA 172:1153-1159, 1960

14. Mihara $M$, Uchiyama $M$ : Determination of malonaldehyde precursor in tissues by thiobarbituric acid test. Anal Biochem 86: $271-278,1978$
15. Murayama $Y$, Vinuela $F$, Ulhoa A, Akiba $Y$, Duckwiler GR, Gobin YP, Vinters HV, Greff RJ: Nonadhesive liquid embolic agent for cerebral arteriovenous malformations: Preliminary histopathological studies in swine rete mirabile. Neurosurgery 43:1164-1175, 1998

16. Sadato A, Wakhloo AK, Hopkins LN: Effects of a mixture of a low concentration of $\mathrm{N}$-butyl cyanoacrylate and etidiol on tissue reactions and permanence on arterial occlusion after embolization. Neurosurgery 47:1 197-1203, 2000

17. Sampei K, Hashimoto N, Kazekawa K, Tsukahara T, Iwata $\mathrm{H}$, Takaichi S: Histological changes in brain tissue and vasculature after intracarotid infusion of organic solvents in rats. Neuroradiology 38:291-294, 1996

18. Swanson BN: Medical use of dimethyl sulfoxide (DMSO). Rev Clin Basic Pharm 5:1-33, 1985

19. Szajner M, Roman T, Markowicz J, Szczerbo-Trojanıwska M: Onyx in endovascular treatment of cerebral arteriovenous malformations. A review. Pol J Radiol 78:35-41, 2013

20. Taki W, Yonekawa Y, Iwata H, Uno A, Yamashita K, Amemiya $\mathrm{H}$ : A new liquid material for embolization of arteriovenous malformations. AJNR Am J Neuroradiol 11:163-168, 1990

21. Vinters HV, Galil KA, Lundie MJ, Kaufmann JC:The Histotoxicity of Cyanoacrylates. A Selective review. Neuroradiology 27:279291, 1985

22. Weber W, Kis B, Siekmann R, Jans P, Laumer R, Kühne D: Preoperative embolization of intracranial arteriovenous malformations with onyx. Neurosurgery 61:244-252, 2007

23. Yamashita K, Taki W, Iwata H, Nakahara I, Nishi S, Sadato A, Matsumoto K, Kikuchi H: Characteristics of ethylene vinyl alcohol copolymer (EVAL) mixtures. AJNR Am J Neuroradiol 15:1103-1105, 1994 